\title{
Desain Pengembangan Kurikulum Pembelajaran Bahasa Arab pada Tujuan Khusus Pemandu Wisata (Tour Guide)
}

\author{
Irvan Maulana Tamsil \\ Universitas Islam Negeri Sunan Kalijaga Yogyakarta \\ Corresponding author: irvantamsil@rocketmail.com
}

\begin{abstract}
Language Arabic, which has now become an international language, has a big contribution in developing science. This Tern shows the existence of active Arabic communication with the languages that exist in this world. By using a language that is understood together, one can establish social relations in the community. The purpose of this study is to design Arabic learning curriculum development specifically for the purpose here of tourism as a tour guide. This research method used library research. The results of the research show that the design learning of Arabic curriculum development is a special purpose tour guide, a tour guide is more, able, fluent and professional in communicating Arabic and knows the ins and outs of the world of tourism, as well as the destination when dealing with tourists from the Middle East.
\end{abstract}

Bahasa arab kini telah menjadi bahasa dunia internasional, memiliki andil besar dalam menumbuh kembangkan ilmu pengetahuan. Tern ini menujukkan adanya komunikasi aktif bahasa arab dengan bahasa-bahasa yang eksis didunia ini. Dengan menggunakan bahasa yang dipahami bersama, seseorang dapat menjalin hubungan sosial dalam masyarakat. Tujuan penelitian ini mendesain pengembangan kurikulum pembelajaran bahasa arab tujuan khusus, untuk tujuan khusus disini tentang kepariwisataan sebagai pemandu wisata. Metode penelitian ini menggunakan telaah pustaka (library research). Hasil penelitian bahwa desain pengembangan kurikulum pembelajaran bahasa arab tujuan khusus pemandu wisata, seorang pemandu wisata lebih mampu,

ISSN 2622-6146 (e) 2622-6138 (p)

(c) 2019 Alsina : Journal of Arabic Studies

http://journal.walisongo.ac.id/index.php/alsina 
lancar dan profesional dalam berkomunikasi bahasa arab dan mengetahui seluk beluk dunia pariwisata, serta tempat destinasi ketika berhadapan dengan wisatawan dari Timur Tengah.

Keywords: Kurikulum, Pembelajaran bahasa Arab, Tujuan khusus Pemandu wisata.

\section{Pendahuluan}

Kurikulum merupakan syarat mutlak dan ciri utama dalam pendidikan formal, sehingga kurikulum adalah bagian yang tak terpisahkan dari proses pendidikan dan pembelajaran. Setiap praktik pendidikan diarahkan untuk mencapai tujuan-tujuan tertentu, baik aspek pengetahuan, sikap, maupun keterampilan. Untuk mengembangkan kompetensi-kompetensi tersebut perlu adanya bahan atau materi yang disampaikan melalui proses pembelajaran menggunakan metode dan media yang yang cocok dengan karakteristik bahan pelajaran. Untuk mengetahui keberhasilan pembelajaran perlu adanya evaluasi dengan cara, jenis dan bentuk tertentu pula. ${ }^{1}$

Pengembangan kurikulum bagian yang esensial dalam proses pendidikan. Sasaran yang ingin dicapai bukan sematamata memproduksi bahan pelajaran melainkan lebih dititik beratkan untuk meningkatkan kualitas pendidikan. Pengembangan kurikulum merupakan proses yang menyangkut banyak faktor yang perlu dipertimbangkan, misalnya pertimbangan akan pernyataan tentang kurikulum, siapa yang terlibat dalam pengembangan kurikulum, bagaimana prosesnya. Menurut Caswell pengembangan kurikulum sebagai alat untuk membantu guru dalam

${ }^{1}$ Muhammad Zaini, Pengembangan kurikulum, ( Yogyakarta: Teras, 2009), hal. 16-17 
melakukan tugas mengajarkan bahan, menarik minat belajar siswa dan memenuhi kebutuhan masyarakat. ${ }^{2}$

Kurikulum mengalami pergeseran seiring dengan dinamika perubahan sosial yang disebabkan oleh berbagai faktor, baik internal maupun eksternal. Karena sifatnya yang dinamis dalam menyikapi perubahan, kurikulum mutlak harus fleksibel. Ketimpangan-ketimpangan dalam desain kurikulum karena kurang respon terhadap perubahan sosial, boleh jadi berkonsekuensi kepada lahirnya output pendidikan yang 'gagap' dalam beradaptasi dengan kondisi sosial yang dimaksud. ${ }^{3}$

Dalam konteks kurikulum bahasa arab, difahami bahwa bahasa arab merupakan alat yang dapat digunakan untuk memahami berbagai ilmu pengetahuan, khususnya ilmu-ilmu agama. ${ }^{4}$ Bahasa arab juga merupakan bahasa yang memiliki kompleksitas yang tinggi, baik secara morfologi, sintaksis, semantic dan leksikal. ${ }^{5}$

Mempelajari bahasa kedua merupakan pekerjaan yang panjang dan kompleks. Mempelajari bahasa bukanlah serangkaian langkah mudah yang bisa diprogram dalam sebuah paduan ringkas. Begitu banyak permasalahan yang ada sehingga kursus-kursus bahasa asing sering menjadi medan latihan yang tidak memadai bagi keberhasilan mempelajari bahasa kedua. Hanya sedikit orang kalau ada, yang berhasil

${ }^{2}$ Ahmad, Pengembangan Kurikulum, (Bandung: Pustaka Setia, 1998), hal.63

${ }^{3}$ Syamsul Bahri, Pengembangan Kurikulum Dasar Dan Tujuanya, Jurnal Ilmiah Islam Future, Vol. XI No. 1 Agustus 2011, Hal. 16

4 Muhammad Asrori, Pengembangan Kurikulum Bahasa Arab Di Pesantren, (Malang: Uin-Malang Pres, 2013), Hal. 4

${ }_{5}^{5}$ Muhajir, Arah Baru Pengajaran Bahasa Arab, (Yogyakarta:FITK UIN Sunan Kalijaga, 2018), Hal. 89 
mencapai kefasihan berbahasa asing melulu dalam batasbatas ruang kelas. ${ }^{6}$

Bahasa merupakan alat utama dalam berkomunikasi serta memiliki daya ekspresi dan informasi yang besar. Sehingga bahasa sangat dibutuhkan oleh manusia karena dengan bahasa manusia bisa menemukan kebutuhan mereka dengan cara berkomunikasi antara satu dengan yang lainya. ${ }^{7}$

Perkembangan zaman yang begitu cepat akibat derasnya arus globalisasi membawa dampak positif pada perkembangan dunia pariwisata, termasuk di Indonesia. Sadar akan besarnya pengaruh positif yang dapat diterima dari dunia kepariwisataan. ${ }^{8}$ Sektor pariwisata telah berperan sebagai penyumbang devisa terbesar kedua setelah migas, menjadi industri atau sektor penting yang dapat diandalkan Pemerintah ke depan untuk menjadi pilar utama pembangunan ekonomi. ${ }^{9}$ Dalam hal tersebut sector pariwisata dapat lebih menarik para wisatawan, khususnya pada sumber daya manusianya, seorang pemandu wisata harus dapat membimbing secara serius, terarah, dan professional dalam melakasanakan tugasnya. Khususnya ketika wisatawan tersebut berasal dari Timur Tengah yang berbicaranya menggunakan bahasa arab. Dikarenakan, pramuwisata (tour guide) sebagai pelaku pariwisata yang merupakan garda terdepan sebab secara langsung bersentuhan dengan wisatawan. Sehingga, wisatawan akan memperoleh informasi

${ }^{6}$ Douglas Brown, Prinsip Pembelajaran Dan Pengajaran Bahasa, (Jakarta: Pearson Education, 2007) Hal. 1

${ }^{7}$ Rohmani Nur Indah dan Abdurrahman, Psikolinguistik, Konsep dan Isu Umum, ( Malang: IKAPI, 2008), hal. 46

${ }^{8}$ Ignatius Javier Tuerah dan Jeane Tuilan, Pelatihan Bahasa Inggris Pada Pemandu Wisata Di Manado, Jurnal Pengabdian Kepada Masyarakat Bidang Kewirausahaan, Vol.1 November 2017, hal. 1

${ }^{9}$ Nanny Rodjinandari dan Bambang Supriadi, Kompetensi Pendampingan Pemandu Wisata Local Sebagai Developers Of People, Jurnal Pesona, Vol.2 Desember 2016 , hal. 73 
atau penjelasan tentang obyek atau destinasi. Oleh karenanya peranan pramuwisata sangat penting.

Rencana Induk Pembangunan Pariwisata Nasional (RIPPARNAS) tahun 2010-2025 diperlukan sebagai acuan operasional pembangunan pariwisata bagi pelaku pariwisata dan pelaku ekonomi, sosial dan budaya. RIPPARNAS menjadi sangat penting, karena memberikan arah pengembangan yang tepat terhadap potensi kepariwisataan dari sisi produk, pasar, spasial, sumber daya manusia, manajemen, dan sebagainya. Sehingga dapat tumbuh dan berkembang secara positif dan berkelanjutan.

Menurut Supriadi Bambang secara teori peningkatan kualitas sumber daya manusia akan berperan sebagai penyumbang dalam meningkatkan kualitas kepuasan wisatawan yang akan kembali, khususnya kualitas sumber daya manusia pramuwisata (tour guide) yang terampil akan menyebabkan pergerakan jumlah wisatawan bertambah banyak dan mempunyai fungsi yang positif. ${ }^{10}$

Dalam hal ini seorang pemandu wisata atau Pramuwisata merupakan orang yang bertugas memberikan bimbingan, informasi, dan petunjuk tentang destinasi. Pekerjaan memandu atau pramuwisata merupakan salah satu profesi yang unik, karena profesi ini membutuhkan kemampuan berbahasa asing serta dapat berinteraksi dengan wisatawan, memiliki pengetahuan luas, fleksibel, penuh pengertian dan kedewasaan berpikir serta kesehatan yang mumpuni. Seorang pemandu wisata diharapakan mamahami seluk beluk dunia kepariwisataan. ${ }^{11}$ Permasalahan yang inti diantaranya

10 Nanny Rodjinandari dan Bambang Supriadi, Kompetensi Pendampingan Pemandu Wisata Local Sebagai Developers Of People, Jurnal Pesona, Vol.2 Desember 2016 , hal. 74

${ }^{11}$ Ignatius Javier Tuerah dan Jeane Tuilan, Pelatihan Bahasa Inggris Pada Pemandu Wisata Di Manado, Jurnal Pengabdian Kepada Masyarakat Bidang Kewirausahaan, Vol.1 November 2017, hal. 1 
pengetahuan, sejarah dan kemampuan berbahasa arab sangat dibutuhkan bagi pemandu wisata khususnya ketika berhadapan dengan wisatawan dari Timur Tengah. Berdasarkan pemaparan diatas, peneliti akan menjelaskan bagaiamana desain pengembangan kurikulum pembelajaran bahasa arab tujuan khusus pada pemandu wisata.

\section{Metode penelitian}

Pengumpulan data dalam penelitian ini menggunakan penelitian kualitatif menempati peran yang sangat penting. Kualitas hasil temuan dalam penelitian kualitatif sangat ditentukan oleh cara pengumpulan data. Dalam penelitian kualitatif kehadiran peneliti sewaktu mengumpulkan data sangat berguna untuk membantu menganalisa dan menginterpretasikan data yang terkumpul. Kreatifitas peneliti memegang peran yang penting walaupun kreatifitas tersebut bersifat pribadi. ${ }^{12}$

Jenis pendekatan menggunakan kepustakaan (library research), Studi pustaka atau kepustakaan dapat diartikan sebagai serangkaian kegiatan yang berkenaan dengan metode pengumpulan data pustaka, membaca dan mencatat serta mengolah bahan penelitian. ${ }^{13}$ Telaah pustaka (library reseach) dapat saja sebatas ringkasan dari sejumlah sumber rujukan, namun telaah pustaka disusun dengan pola oraginasasi tertentu yang dikombinasikan dengan ringkas dan sintesis. ${ }^{14}$

Adapun dalam peneletian ini sumber yang digunakan dari berbagai jurnal-jurnal dan buku-buku serta sumber lainya yang relevan.

12 Bambang Setiyadi, Metode Penelitian Untuk Pengajaran Bahasa Asing, (Yogyakarta: Graha Ilmu, 2006), Hal. 237

13 Mestika Zed, Metode Penelitian Kepustakaan, ( Jakarta: Yayasan Obor Indonesia, 2003), Hal. 3

14 Tatang Ary Gumanti, Yunidar, dan Syahruddin, Metodologi Penelituan Pendidikan, (Jakarta: Mitra Wacana Media,2016), Hal. 89 


\section{Konsep Kurikulum}

Kurikulum secara etimologis (bahasa), berasal dari bahasa Yunani curir yang artinya pelajari dan curere yang berarti tempat berpacu. Istilah kurikulum berasal dari dunia olah raga pada zaman romawi kuno di Yunani yang mengandung pengertian suatu jarak yang harus ditempuh oleh pelari dari garis start sampai garis finish. Kurikulum dalam bahasa arab manhaj yang artinya jalan terang yang dilalui manusia diberbagai kehidupan. Kurikulum pendidikan manhaj addirosah dalam kamus tarbiyah adalah seperangkat perencanaan dan media yang dijadikan acuan oleh lembaga pendidikan dalam mewujudkan tujuan-tujan pendidikan.

Menurut Zakiyah Darajat, dkk. Kurikulum sebagai suatu program yang direncanakan dalam bidang pendidikan dan dilaksanakan untuk mencapai sejumlah tujuan tertentu. Undang-undang RI No.20 tahun 2003 tentang Sisdiknas, pasal 1 ayat 19 bahwa kurikulum adalah seperangkat rencana dan pengaturan mengenai tujuan, isi, dan bahan pelajaran serta cara yang digunakan sebagai pedoman penyelenggaraan kegiatan pembelajaran untuk mencapai tujuan pendidikan tertentu. ${ }^{15}$

Dalam pengertian diatas, mencakup didalamnya sebuah pembelajaran diantara subyek didik dalam melakukan transformasi pengetahuan, keterampilan dengan menggunakan berbagai pendekatan, proses pembelajaran atau menggunakan metode belajar dan mendayagunakan segala teknologi pembelajaran. Namun demikian, bahwa konsep kurikulum sebagai urutan pelajaran tetap menjadi

${ }^{15}$ Maksudin dan Qoim Nurani, Pengembangan Kurikulum Pembelajaran Bahasa Arab,( Yogyakarta:Pascasarjana FITK UIN SUKA, 2018), Hal. $39-40$ 
dasar yang subtansial dalam rancangan dan menyusun desain kurikulum. ${ }^{16}$

Arahan atau bimbingan dari lembaga atau institusi terhadap warga belajarnya dimaksudkan agar kegiatan pengajaran atau proses belajar mengajar yang dilakukan dapat berjalan lancar. Dengan kata lain, unsur pokok dalam kurikulum berkenaan dengan perencanaan kegiatan peserta didik yaitu kegiatan-kegiatan yang dilakukan selama bersekolah dalam rangka mencapai tujuan pendidikan yang ditetapkan. ${ }^{17}$

\section{Pengembangan Kurikulum Bahasa Arab}

Dalam pengembangan kurikulum ${ }^{\mathbf{1 8}}$ pengembangan tidak hanya menonjolkan atau mementingkan satu filsafat tetapi juga mempertimbangkan falsafah lain. Antara lain: filsafat Negara, filsafat lembaga pendidikan, dan staf pengajar atau pendidik. 19

Taba menganjurkan untuk lebih mempunyai informasi tentang masukan (input) pada setiap langkah proses kurikulum. Secara khusus, menganjurkan untuk menggunakan pertimbangan ganda terhadap isi (organisasai kurikulum yang logis) dan individu pelajar. Untuk kurikulum biasanya berisi beberapa seleksi dan organisasi isi, itu

16 Muhammad Asrori, Pengembangan Kurikulum Bahasa Arab Di Pesantren, (Malang: Uin-Malang Pres, 2013), Hal.26

17 Ahmad, Pengembangan Kurikulum, (Bandung: Pustaka Setia, 1998), hal. 59

18 Pengembangan kurikulum adalah perencanaan kesempatan-kesempatan belajar yang dimaksudkan untuk membawa siswa kearah perubahan-perubahan yang diinginkan dan menilai hingga mana perubahanperubahan itu telah terjadi pada siswa. Lihat dalam Oemar Hamalik, Menejemen Pengembangan Kurikulum, (Bandung: Rosda karya,2012), hal. 97

19 Abdul Manab, Manajemen Perubahan Kurikulum , (Yogyakarta: Kalimedia, 2015), hal.65-66 
merupakan manifestasi dari bentuk-bentuk belajar dan mengajar.

Taba mengungkapkan bahwa pengembangan kurikulum ilmiah atau rasional memerlukan penggambaran analisis terhadap masyarakat dan budaya, mempelajari anak didik dan proses belajarnya, serta menganalisis hakikat pengetahuan agar dapat menentukan tujuan-tujuan sekolah dan hakikat kurikulum itu sendiri. Kemudian Taba mengklaim bahwa jika pengembangan kurikulum menjadi logis, program yang teratur itu harus diuji secara tepat berdasarkan peraturan kurikulum yang dibuat sebagaimana hal itu diterapkan. ${ }^{20}$

Prinsip-prinsip yang digunakan dalam pengembangan komponen-komponen kurikulum secara khusus (tujuan, isi, metode, dan evaluasi). Satu wilayah dengan wilayah lainya memiliki karakteristik yang berbeda dalam beberapa aspek. Prinsip-prinsip pengembangan kurikulum lainya yaitu merujuk pada prinsip-prinsip pengembangan komponenkomponen kurikulum, yang antara satu komponen dengan komponen yang lainnya memiliki prinsip yang tidak sama. ${ }^{21}$

Prinsip berkenaan dengan tujuan pendidikan. Tujuan menjadi pusat kegiatan dan arah semua kegiatan pendidikan perumusan komponen-komponen kurikulum hendaknya mengacu pada tujuan pendidikan. Tujuan pendidikan mencakup tujuan yang bersifat umum atau berjangka panjang, jangka menengah, dan jangka pendek (tujuan khusus). Perumusan tujuan pendidikan bersumber pada:

a. Ketentuan dan kebijaksanaan pemerintah, yang dapat ditemukan dalam dokumen-dokumen lembaga Negara mengenai tujuan, dan strategi pembangunan termasuk didalamnya pendidikan.

${ }^{20}$ Abdullah dan Safarani, Pengembangan Kurikulum, (Jakarta :Raja Grafindo Persada, 2014), hal. 127-128

${ }^{21}$ Cepy Riana, Kurikulum dan Pembelajaran, (Jakarta :Raja Grafindo Persada, 2014), hal. 71 
b. Survey mengenai persepsi orang tua/masyarakat tentang kebutuhan mereka yang dikirimkan melalui angket atau wawancara dengan mereka.

c. Survey tentang pandangan para ahli dalam bidang-bidang tertentu.

d. Survey tentang man power.

e. Pengalaman Negara-negara lain dalam masalah yang sama.

f. Penelitian. ${ }^{22}$

Dalam pengembangan kurikulum terdapat sejumlah prinsip umum yang dipakai sebagai rambu-rambu atau pedoman agar kurikulum yang dihasilkan benar-benar sesuai dengan keinginan yang diharapkan semua pihak, yakni peserta didik, keluarga, lembaga pendidikan, masyarakat, dan juga pemerintah.

Pengembangan kurikulum harus berdasarkan pada prinsip-prinsip tertentu. Prinsip yang dianut dalam pengembangan kurikulum merupakan kaidah, norma pertimbangan atau aturan yang menjiwai kurikulum. Pengembangan kurikulum dapat menggunakan prinsipprinsip yang telah berkembang didalam kehidupan seharihari. Oleh sebab itu prinsip pengembangan kurikulum disuatu sekolah berbeda dengan prinsip yang digunakan di sekolah lain.

Esensi dari pengembangan kurikulum adalah proses identifikasi, analisis, sintesis, evaluasi, pengambilan keputusan, dan kreasi elemen-elemen kurikulum. Proses pengembangan kurikulum harus dapat dilakukan secara efektif dan efisien. Untuk itu, para pengembang kurikulum perlu memperhatikan prinsip-prinsip pengembangan

22 Nana Syaodih Sukmadinata, Pengembangan Kurikulum, (Bandung: Remaja Rosdakarya, 2012), Hal. 152-153 
kurikulum agar bisa bekerja secara mantap, terarah, dan hasilnya bisa dapat dipertanggungjawabkan. ${ }^{23}$

Tujuan pengembangan kurikulum yaitu goal dan objektives. Tujuan sebagai goal dinyatakan dalam rumusan yang lebih abstrak dan bersifat umum, dan pencapaianya relative dalam jangka panjang. Adapun tujuan sebagai objektives lebih bersifat khusus, operasional, dan pencapaiannya dalam jangka pendek. Aspek tujuan, baik yang dinyatakan dalam goals maupun objektives, memakan peran yang sangat penting dalam pengembangan kurikulum. ${ }^{24}$

Pengembangan kurikulum pembelajaran dalam kajian ini adalah suatu upaya yang dilakukan terus menerus berkesinambungan bertahap terhadap kurikulum pembelajaran bahasa arab melalui proses kegiatan pembelajaran yang terencana untuk mengetahui dan menilai transformasi ilmu, sikap, mental, dan perilaku kebahasaaraban siswa/mahasiswa yang dilakukan secara professional dan berorientasi kepada tujuan yang telah ditentukan terhadap keadaan suatu objek pembelajaran bahasa arab.

Paling tidak ada enam faktor yang mendasari pengembangan kurikulum bahasa,yaitu: analisis kebutuhan, penetapan tujuan, rancangan silabus, metodologi, pengujian, penilaian..$^{25}$

Sesungguhnya manusia itu sangat membutuhkan komunikasi dalam konteks sosial. intensifitas komunikasi ilmu pengetahuan maupun ilmu agama itu dapat dibangun melalui bahasa arab. Bahasa arab itu juga memiliki sentral pengkajian

${ }^{23}$ Zainal Arifin, Konsep dan Model Pengembangan Kurikulum, (Bandung: Remaja Rosdakarya, 2011), hal. 27-28

24 Oemar Hamalik, Dasar-Dasar Pengembangan Kurikulum, (Bandung: Remaja Rosdakarya, 2013), Hal. 187

${ }^{25}$ Maksudin, dan Qoim Nurani, Pengembangan Kurikulum Pembelajaran Bahasa Arab,(Yogyakarta:Pascasarjana FITK UIN SUKA, 2018), Hal. 227-228 
yang perlu dijelaskan secara benar sesuai dengan kebahasaan arab itu sendiri. Hal ini sebagaimana ditegaskan oleh Abd. alRahman B. Ibrahim al-Fawzan sebagai berikut: " Bahasa itu memiliki empat keterampilan yaitu: kalam, istma', qiro'ah, dan kitabah. Sedangkan batu loncatan atau perantara yang dibuat mentransformasikan materi pembicaraan adalah suara berbagai ungkapan komunikasi secara langsung diantara orang yang berbicara dan orang yang mendengarkan. Sementara keterampilan membaca dan menulis itu prantara yang dijadikan alat komunikasi adalah huruf yang ditulis. Dan menjadi nyatalah komunikasi dengan dua maharah (membaca dan menulis) ini tanpa batas ruang dan waktu. Dari sisi lain, seseorang akan mendapatkan berbagai ilmu pengetahuan dan pengalaman, ungkapan-ungkapan berupa dua maharah mendengarkan dan membaca, sehingga keduanya maharah ini termasuk keterampilan menerima. Dan seseorang dengan keterampilan kalam dan kitabah dapat menyebarkan risalahnya berupa pengetahuan, pengalaman secara produktif. Perlu diketahui bahwa seseorang akan membutuhkan bahasa yang lebih bagus dan jelas, dia juga membutuhkan keterampilan mendengar dan membaca, suatu waktu ia akan membutuhkan bahasa yang paling sedikit tingkat kesulitanya, yaitu keterampilan berbicara dan menulis".

Selanjutnya juga dijelaskan pula unsur-unsur bahasa arab yang dapat difragmentasikan sesuai dengan redaksinya sebagai berikut: " sebagian ulama ahli bahasa memberi nama dengan sebutan tempat-tempat kedudukan bahasa yaitu: ada tiga unsur suara kosa kata dan gramatika bahasa. Tiga unsur bahasa itu merupakan substansi materi yang dapat menolong seseorang yang belajar untuk belajar materi-materi kebahasaan, barang siapa yang tidak dapat menguasai terhadap tiga unsur bahasa itu maka ia tidak mampu menguasai terhadap materi-materi kebahasaan, dan berbagai cakupanya". 
Kurikulum bahasa arab memiliki kurikulum tersendiri untuk mencapai tujuan yang diharapkan dalam proses pembelajaranya. Karena sesungguhnya, sebagai tolok ukur keberhasilan bahasa arab dalam ruang lingkup lembaga pendidikan yang diidealkan itu yang sesuai dengan mutu yang standar tidak dapat dilepas-pisahkan kurikulum yang kontruktif pula. ${ }^{26}$

Dalam kurikulum tujuan memegang peranan penting, karena tujuan akan mengarahkan semua kegiatan pembelajaran dan memberi warna setiap komponen kurikulum lainya. Tujuan kurikulum dirumuskan berdasarkan dua hal yaitu: pertama, perkembangan tuntutan, kebutuhan dan kondisi masyarakat. Kedua, didasari oleh pemikiranpemikiran dan terarah pada pencapaian nilai-nilai filosofis, terutama falsafah Negara. ${ }^{27}$

\section{Tujuan Khusus Pemandu Wisata (Tour Guide)}

Pariwisata mempunyai potensi yang sangat besar untuk berkembang dimasa yang akan datang dan akan mengalami perubahan yang sangat besar secara alami. Hal ini merupakan sesuatu yang sangat penting karena mengalami perkembangan yang sangat hebat apabila dilihat dari sudut pandang statistic pariwisata. ${ }^{28}$ Pramuwisata disebut juga Pemandu Wisata atau Tour Guide dalam Bahasa Inggris. Di Indonesia, secara nasional telah dibentuk organisasi yang mewadahi profesi ini, yaitu Himpunan Pramuwisata Indonesia atau HPI. Organisasi ini telah memiliki jaringan ke seluruh provinsi di Indonesia. Di beberapa daerah juga terbentuk sejumlah organisasi serupa yang bersifat lokal.

${ }^{26}$ Muhammad Asrori, Pengembangan Kurikulum Bahasa Arab Di Pesantren, (Malang: Uin-Malang Pres, 2013), Hal. 118-122

27 Sholeh Hidayat, Kurikulum Baru,( Bandung: Remaja Rosdakarya, 2013), Hal. 51-52

${ }^{28}$ Muljadi dan Andi Hermawan, Kepariwisataan Dan Perjalanan, ( Jakarta:Rajagrafindo Persada, 2016), Hal. 2 
Menurut Kamus Besar Bahasa Indonesia (KBBI) Pramuwisata merupakan petugas pariwisata yg berkewajiban memberi petunjuk dan informasi yg diperlukan wisatawan. Menurut Peraturan Menparpostel RI, Pramuwisata adalah seseorang yang bertugas memberikan bimbingan, penjelasan dan petunjuk tentang obyek wisata serta membantu keperluan wisatawan lainnya. Menurut European Committe For Standardisation: " tourist guide is a person who guide visitiors in the language of their choice and interprets the cultural and natural heritage of an area which person normally possesses an area-specific qualification usually issued and /or recognized by the appropriate authority".29

Secara umum, seseorang yang hendak menjadi pramuwisata di Indonesia disyaratkan untuk memiliki licence yang diterbitkan oleh HPI. Tata Nuriata mengatakan bahwa pramuwisata berasal dari bahasa Sansekerta yaitu pramu, wis, dan ata. Pramu berarti pelayan atau orang yang melayani, wis berarti tempat dan ata berarti banyak. Pendapat umum mengartikan wisata sebagai keliling atau perjalanan sehingga dalam hal ini pramuwisata dapat dikatakan sebagai petugas yang melayani orang yang sedang melakukan perjalanan wisata. 30

Pendamping, tentu memiliki peran berbeda dengan pola pengajaran. Pendamping, lebih berperan sebagai Pertemanan bukan yang didampingi dan siap membantu kesulitan. Pendamping pengajaran bukanlah seorang pengawas yang hanya mencari-cari kesalahan yang didampingi. Perencanaan dan pengembangan sumber daya manusia memiliki pola

${ }^{29}$ Ignatius Javier Tuerah, Jeane Tuilan, Pelatihan Bahasa Inggris Pada Pemandu Wisata di Manado, Jurnal Pengabdian Kepada Masyarakat Bidang Kewirausahaan, Vol.1 November 2017, hal. 2

30 Ignatius Javier Tuerah, Jeane Tuilan, Pelatihan Bahasa Inggris Pada Pemandu Wisata di Manado, Jurnal Pengabdian Kepada Masyarakat Bidang Kewirausahaan, Vol.1 November 2017, hal. 3 
pendidikan keterampilan untuk peningkatan kualitas orang lain dalam hal ini adalah pemandu wisata atau disebut developers of people . Manajemen supervisi atau pendamping, lebih berperan sebagai relasi yang siap membantu kesulitan dalam pengembangan pengajaran dan bukanlah seorang manager yang hanya mencari kelemahan orang lain. Peran Pendamping yang utama, ada empat hal, yaitu:

a. Sebagai koordinator, berperan mengkoordinasikan program-program dan bahan-bahan yang dibutuhkan untuk meningkatkan kinerja yang didampingi dalam pembelajaran dan harus membuat laporan mengenai pelaksanaan programnya.

b. Sebagai konsultan, Pendamping harus memiliki kemampuan sebagai spesialis dalam masalah materi, metodologi pembelajaran, dan pengembangan, sehingga Pendamping dapat membantu yang didampingi baik secara individual maupun kelompok.

c. Sebagai pemimpin kelompok (group leader), Pendamping harus memiliki kemampuan memimpin, memahami dinamika kelompok, dan menciptakan berbagai bentuk kegiatan kelompok.

d. Sebagai evaluator, Pendamping harus dapat memberikan bantuan pada yang didampingi untuk dapat mengevaluasi pelaksanaan pembelajaran dan materi, serta harus mampu membantu mengidentifikasi permasalahan yang dihadapi yang didampingi, membantu melakukan penelitian dan pengembangan dalam pembelajaran dan sebagainya. ${ }^{31}$

Pariwisata berkembang karena ada gerakan manusia dalam mencari sesuatu yang belum diketahui, menjelajah wilayah baru, mencari perubahan suasana, atau untuk

${ }^{31}$ Nanny Rodjinandari dan Bambang Supriadi, Kompetensi Pendampingan Pemandu Wisata Local Sebagai Developers Of People, Jurnal Pesona, Vol.2 Desember 2016, hal. 74-75 
mendapat perjalanan baru. Dewasa ini pariwisata telah menjadi salah satu industri andalan utama dalam menghasilkan devisa berbagai Negara. Pariwisata cukup menjanjikan sebagai primadona ekspor karena beberapa ciri positifnya. ${ }^{32}$

Pariwisata pada dasarnya merupakan fenomena perjalanan manusia secara perorangan atau kelompok dengan berbagai macam tujuan. Manusia melakukan perjalanan secara bebas atas kemauan sendiri dengan tujuan damai untuk memenuhi kebutuhan hakikinya yaitu untuk mengetahui, mempelajari, menemukan dan mengalami secara langsung segala sesuatunya yang tidak ada di tempat tinggalnya dan mencari keunikan atau kekhasan baik alam, budaya maupun kondisi geografis yang berbeda-beda. Pada saat kegiatan kepariwisataan berlangsung, wiasatawan melakukan berbagai aktifitas wisata guna memenuhi kebutuhan untuk keingintahuan. 33

Terdapat komponen-komponen yang dapat dijabarkan dari suatu produk pariwisata, adapun komponen-komponen tersebut yakni atraksi destinasi, fasilitas destinasi, aksesibilitas, image dan harga.

a). Atraksi Destinasi

Elemen-elemen yang terkandung dalam destinasi dan lingkungan di dalamnya yang secara individual atau kombinasinya memegang peran penting dalam memotivasi wisatawan untuk berkunjung ke destinasi tersebut. Atraksi merupakan unsur-unsur alami atau buatan, yang menjadi daya tarik bagi suatu destinasi wisata untuk wisatawan, khususnya wisman yang akan melakukan perjalanan ke luar

32 Sedarmayanti, Membangun Dan Mengembangkan Kebudayaan Industry Pariwisata,( Bandung: Refika Aditama, 2014), Hal. 2

33 Muljadi dan Andi Hermawan, Kepariwisataan Dan Perjalanan, (Jakarta:Rajagrafindo Persada, 2016), Hal. 48-49 
negeri untuk berlibur. Atraksi destinasi bisa berupa atraksi alam, seperti landscape, pantai, pegunungan, iklim, lembah; atraksi buatan seperti kota bersejarah, taman dan resort; atraksi budaya seperti atraksi teatrikal, drama, festival, museum dan galeri; atraksi sosial seperti kesempatan berbaur dengan masyarakat di daerah tujuan wisata dan ikut mengalami cara hidup bersama mereka.

b). Fasilitas Destinasi

Elemen dalam destinasi atau hubungan dengan destinasi yang memungkinkan wisatawan tinggal di destinasi tersebut untuk menikmati atau berpartisipasi dalam atraksi yang ditawarkan.

c). Aksesibilitas

Mudah atau sulitnya wisatawan menjangkau destinasi yang diinginkannya. Infrastruktur yang memadai mendukung akses wisman dalam melakukan kunjungan, tersedianya perjalanan melalui laut yang aman serta tersedia setiap jamnya dan adanya akses internasional melalui perjalanan udara menuju tempat tujuan merupakan keberhasilan yang dimiliki.

d). Image

Ide atau kepercayaan yang dimiliki wisatawan tentang produk atau pelayanan yang mereka beli atau akan beli. Imej destinasi tidak selalu berdasarkan pengalaman atau fakta, tetapi dapat dibentuk sedemikian rupa sehingga menjadi faktor motivasi atau pendorong yang kuat untuk melakukan perjalanan wisata ke destinasi tersebut. Memutuskan pergi ke suatu tempat dalam melakukan perjalanan wisata dibutuhkan motivasi atau dorongan untuk meyakinkan diri bahwasanya tidak salah dalam memilih tempat tujuan berwisata, terlebih lagi berwisata ke luar negeri yang dimana tempat tersebut mempunyai kebiasaan, adat dan aturan yang berbeda.

e). Harga 
Jumlah keseluruhan dari biaya-biaya selama perjalanan wisata yang mencakup akomodasi, makanan dan minuman, biaya perjalanan dan partisipasi dalam pelayanan yang dikonsumsi selama berada di destinasi yang dituju. ${ }^{34}$

\section{Desain pengembangan kurikulum pembelajaran bahasa arab pada tujuan khusus pemandu wisata}

Desain kurikulum merupakan proses dari rencana kurikulum yang senantiasa mengarah kepada tercapainya tujuan pendidikan. Dalam mengembangkan desain kurikulum terlebih dahulu harus mengidentifikasi elemen-elemen dasar. Elemen kurikulum meliputi tujuan, cara belajar, isi pengalaman belajar, dan evaluasi.

Desain kurikulum berhubungan erat dengan tujuan dasar dari sekolah bersangkutan, sehingga betul-betul efesien dan tepat bila diterapkan nanti. Karena itu desain kurikulum merealisasikan pada teori, konsep dan pandangan tentang kurikulum. ${ }^{35}$

Proses pengembangan kurikulum menurut Hamid Hasan, harus meliputi tiga dimensi kurikulum yaitu kurikulum sebagai ide, kurikulum sebagai dokumen, dan kurikulum sebagai proses. Ketiga dimensi kurikulum ini saling berkaiatan antara yang satu dengan yang lainya. Kurikulum sebagai proses dilaksanakan dengan berbagai kebijakan kurikulum. ${ }^{36}$ Pengembangan kurikulum merupakan sesuatu hal yang dapat terjadi kapan saja sesuai dengan kebutuhan. Munculnya peraturan perundang-undangan yang baru telah membawa implikasi terhadap paradigma baru dalam proses

${ }^{34}$ Supriono, Analisis Deskripsi Potensi Pariwisata Kota Batam Dalam Rangka Menjaring Wisatawan Manca Negara, Jurnal Pariwisata Terapan, Vol. 1 N0. 1 2017, Hal 101-13

${ }^{35}$ Hendyat Soetopo dan Wasty Soemanto, Pembinaan dan Pengembangan Kurikulum, ( Jakarta: Ikapi, 1986), hal. 75

${ }^{36}$ Muhammad Zaini, Pengembangan kurikulum, ( Yogyakarta: Teras, 2009), hal. 16-17 
perkembangan kurikulum. ${ }^{37}$ Bahasa arab merupakan penghubung dalam pergaulan manusia sehari-hari, baik individu dengan individu, individu dengan masyarakat, dan masyarakat dengan bangsa tertentu. Hal ini dapat mengkomunikasikan dan menyampaikan maksud tertentu dan mencurahkan suatu perasaan tertentu kepada orang lain agar dapat dipahami dan dimengerti. 38

Dalam tujuan khusus untuk kepariwisataan, setiap tahun banyak turis berdatangan dari berbagai penjuru dunia, khususnya Timur Tengah menuju Indonesia. Semakin banyak orang yang melakukan perjalanan wisata ke Indonesia, maka semakin banyak pula para pelaku bisnis yang membangun fasilitas guna menunjang kebutuhan para wisatawan. Menurut Hutasoit dan Sari, ditinjau dari segi ekonomi maka kegiatan pariwisata dapat memberikan sumbangan terhadap penerimaan daerah yang bersumber dari pajak, retribusi parkir dan karcis atau dapat mendatangkan devisa dari para wisatawan mancanegara yang berkunjung.

Hal ini sejalan dalam menyambut wisatawan dari daerah timur tengah (Arab), sesungguhnya berdampak besar pada aspek peningkatan wisatawan timur tengah yang hadir ke Indonesia. Hal tersebut sebagaimana yang diungkapkan oleh Kurt, et al. bahwa peningkatan kemampuan komunikasi dan keterampilan bekerja akan berpengaruh terhadap peningkatan jumlah wisatawan. ${ }^{39}$

Terdapat komponen yang harus diperhatikan dalam kurikulum yaitu tujuan pembelajaran, materi pembelajaran,

37 Oemar Hamalik, Menejemen Pengembangan Kurikulum, (Bandung: Rosda karya,2012), hal. 90

38 Muhammad Asrori, Pengembangan Kurikulum Bahasa Arab di Pesantren, (Malang:UIN-Maliki Press, 2013), Hal. 108-109

39 Euis Ernawati, Perencanaan Pembelajaran Bahasa Arab Di Perguruan Tinggi Pariwisata, Jurnal Pendidikan Bahasa Arab Dan Kebahasaaraban, Vol. 5 Juni 2018, Hal.21-22 
strategi/metode pembelajaran, media pembelajaran, dan evaluasi pembelajaran..$^{40}$

1. Tujuan pembelajaran, Seluruh upaya guru dan peserta didik akan terikat oleh sesuatu yang mereka inginkan tersebut, sehinga penetapan tujuan menjadi sangat penting. ${ }^{41}$ Dalam hal ini untuk menyambut wisatawan khususnya timur tengah agar dapat berkomunikasi dengan baik. ${ }^{42}$

2. Materi pembelajaran, Sumber belajar dapat diambil dari berbagai sumber yang dianggap dapat membantu peserta didik mencapai kompetensi yang ditetapkan. ${ }^{43}$ Seperti halnya materi sejarah tempat wisata, khiwar untuk latihan berdialog antara guru dengan peserta didik, atau peserta didik dengan peserta didik yang lain.

3. Metode pembelajaran, Metode digunakan untuk merealisasikan strategi yang telah ditetapkan. Dengan demikian, metode dalam rangkaian system pembelajaran memegang peranan yang sangat penting. Keberhasilan implementasi strategi pembelajaran sangat tergantung pada cara guru menggunakan metode pembelajaran, karena suatu strategi pembelajaran hanya mungkin dapat diimplementasikan melalui penggunaan metode pembelajaran. ${ }^{44}$ Metode langsung diaktualisasikan dalam proses pembelajaran bahasa arab, baik di Negara timur tengah maupun di negara-negara islam asia termasuk

\footnotetext{
وليد خضـــر الزند و هاني حتمل عبيدات, المناهج :عالم الكتب الحديث. ـ ـ ب, ص. 340 التعليمية, بيروت

${ }^{41}$ Hartono, Pendidikan Integrasi,(Purwokerto: Stain Pres, 2011), Hal. 42

42 Euis Ernawati, Perencanaan Pembelajaran Bahasa Arab Di Perguruan Tinggi Pariwisata, Jurnal Pendidikan Bahasa Arab Dan Kebahasaaraban, Vol. 5 Juni 2018, Hal. 22

${ }^{43}$ Hartono, Pendidikan Integrasi,(Purwokerto: Stain Pres, 2011), Hal. 45-46

${ }^{44}$ Wina Sanjaya, Strategi Pembelajaran Berorientasi Standart Proses Pendidikan,( Jakarta: Kencana, 2007), Hal. 147
} 
Indonesia. Metode langsung tidak menggunakan bahasa ibu ketika proses pembelajaran interaktif berlangsung, namun Juwairiyah menegaskan lebih lanjut dalam kondisi tertentu (darurat) masih diperbolehkan menggunakan bahasa ibu. ${ }^{45}$

4. Media pembelajaran, Dalam proses pembelajaran, media yang digunakan guru harus sesuai dengan tujuan pembelajaran yang telah ditetapkan sehingga mampu merangsang dan menumbuhkan minat siswa dalam belajar. Dengan demikian, akan tumbuh interaksi antara media pembelajaran dan siswa dalam belajar. Adanya interaksi positif antara media pembelajaran dan siswa pada akhirnya akan mampu mempercepat proses pemahaman siswa terhadap isi pembelajaran. ${ }^{46}$ agar pembelajaran bahasa Arab lebih menarik seperti dengan menonton video bagaimana orang Arab berkomunikasi agar bisa berbicara dengan wisatawan arab ketika menjadi tour guide. ${ }^{47}$

5. Evaluasi pembelajaran, Evaluasi pembelajaran merupakan langkah yang penting untuk memperoleh informasi mengenai hasil pembelajaran. Informasi mengenai ketercapaian tujuan pembelajaran yang telah ditetapkan, khususnya yang terkait dengan keberhasilan peserta didik dalam proses pembelajaran. ${ }^{48}$ Dengan cara mendatangkan orang Arab (timur tengah), sehingga seorang peserta didik mempraktikan secara langsung berdialog dengan orang

${ }^{45}$ Zulhannan, Teknik Pembelajaran Bahasa Arab Interaktif, (Jakarta: Rajagrafindo Persada, 2014), Hal. 37-38

${ }^{46}$ Made Wena, Strategi Pembelajaran Inovatif Kontemporer, ( Jakarta: Sinar Grafika Offset, 2009), Hal. 10

47 Euis Ernawati, Perencanaan Pembelajaran Bahasa Arab Di Perguruan Tinggi Pariwisata, Jurnal Pendidikan Bahasa Arab Dan Kebahasaaraban, Vol. 5 Juni 2018, Hal 29 $51-52$

${ }^{48}$ Hartono, Pendidikan Integrasi,(Purwokerto: Stain Pres, 2011), Hal. 
Timur Tengah langsung menggunakan bahasa arab yang seolah-olah menjadi pemandu wisata.

\section{Simpulan}

Berkaitan dengan tujuan khusus dalam desain pengembangan kurikulum pembelajaran bahasa arab dalam hal ini untuk kepariwisataan, seorang tour guide harus lebih berperan sebagai relasi yang siap membantu kesulitan dalam pengembangan pengajaran dan bukanlah seorang manager yang hanya mencari kelemahan orang lain.

Beberapa komponen kurikulum diantaranya tujuan pembelajaran dapat menyambut wisatawan khususnya wisatawan timur tengah dengan berkomunikasi dengan baik dan lancar, materi pembelajaran yang diajarkan mengenai percakapan (khiwar) yang bersangkutan tentang pariwisata, metode pembelajaran dengan secara langsung (direct methode) menggunakan bahasa arab, media pembelajaran yang digunakan dengan melihat video orang arab ketika dalam berkomunikasi, dan terakhir evaluasi pembelajaran ketercapaian tujuan pembelajaran yang telah ditetapkan, pada keberhasilan peserta didik dalam berinteraksi menggunakan bahasa arab ketika berhadapan dengan orang Timur Tengah.

\section{Daftar Pustaka}

وليد خضر الزند و هاني حتمل عبيدات, المناهج التعليمية, بيروت عالم الكتب

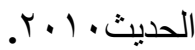

Abdullah dan Safarani, Pengembangan Kurikulum, Jakarta: Raja Grafindo Persada, 2014.

Ahmad, Pengembangan Kurikulum, Bandung: Pustaka Setia, 1998.

Arifin, Zainal, Konsep dan Model Pengembangan Kurikulum, Bandung: Remaja Rosdakarya,2011. 
Asrori, Muhammad, Pengembangan Kurikulum Bahasa Arab Di Pesantren, Malang: Uin-Malang Pres, 2013.

Bahri, Syamsul, Pengembangan Kurikulum Dasar Dan Tujuanya, Jurnal Ilmiah Islam Future, Vol. XI No. 1 Agustus 2011.

Brown, Douglas, Prinsip Pembelajaran Dan Pengajaran Bahasa, Jakarta: Pearson Education, 2007.

Ernawati, Euis, Perencanaan Pembelajaran Bahasa Arab Di Perguruan Tinggi Pariwisata, Jurnal Pendidikan Bahasa Arab Dan Kebahasaaraban, Vol. 5 Juni 2018.

Gumanti, Tatang Ary, Yunidar, dan Syahruddin, Metodologi Penelitian Pendidikan, Jakarta: Mitra Wacana Media, 2016.

Hartono, Pendidikan Integrasi, Purwokerto: Stain Pres, 2011.

Hamalik, Oemar, Menejemen Pengembangan Kurikulum, Bandung: Rosda Karya, 2012.

Hidayat, Sholeh, Kurikulum Baru, Bandung: Remaja Rosdakarya, 2013.

Indah, Rohmani Nur dan Abdurrahman, Psikolinguistik, Konsep dan Isu Umum, Malang: IKAPI, 2008.

Maksudin, dan Qoim Nurani, Pengembangan Kurikulum Pembelajaran Bahasa Arab, Yogyakarta: Pascasarjana FITK UIN SUKA, 2018.

Manab, Abdul, Manajemen Perubahan Kurikulum , Yogyakarta: Kalimedia, 2015.

Muhajir, Arah Baru Pengajaran Bahasa Arab, Yogyakarta: FITK UIN Sunan Kalijaga, 2018.

Muljadi dan Andi Hermawan, Kepariwisataan Dan Perjalanan, Jakarta:Rajagrafindo Persada, 2016. 
Riana, Cepy, Kurikulum dan Pembelajaran, Jakarta :Raja Grafindo Persada, 2014.

Rodjinandari, Nanny dan Bambang Supriadi, Kompetensi Pendampingan Pemandu Wisata Local Sebagai Developers Of People, Jurnal Pesona, Vol.2 Desember 2016.

Sanjaya, Wina, Strategi Pembelajaran Berorientasi Standart Proses Pendidikan, Jakarta: Kencana, 2007.

Sedarmayanti, Membangun Dan Mengembangkan Kebudayaan Industry Pariwisata, Bandung: Refika Aditama, 2014.

Setiyadi, Bambang, Metode Penelitian Untuk Pengajaran Bahasa Asing, Yogyakarta: Graha Ilmu, 2006.

Soetopo, Hendyat dan Wasty Soemanto, Pembinaan dan Pengembangan Kurikulum, Jakarta: Ikapi, 1986.

Sukmadinata, Nana Syaodih, Pengembangan Kurikulum, Bandung: Remaja Rosdakarya, 2012.

Supriono, Analisis Deskripsi Potensi Pariwisata Kota Batam Dalam Rangka Menjaring Wisatawan Manca Negara, Jurnal Pariwisata Terapan, Vol. 1 No. 12017.

Tuerah, Ignatius Javier dan Jeane Tuilan, Pelatihan Bahasa Inggris Pada Pemandu Wisata di Manado, Jurnal Pengabdian Kepada Masyarakat Bidang Kewirausahaan, Vol.1 November 2017.

Wena, Made, Strategi Pembelajaran Inovatif Kontemporer, Jakarta: Sinar Grafika Offset, 2009.

Zaini,Muhammad, Pengembangan kurikulum, Yogyakarta: Teras, 2009.

Zulhannan, Teknik Pembelajaran Bahasa Arab Interaktif, Jakarta: Rajagrafindo Persada, 2014.

Zed, Mestika, Metode Penelitian Kepustakaan, Jakarta: Yayasan Obor Indonesia, 2003. 